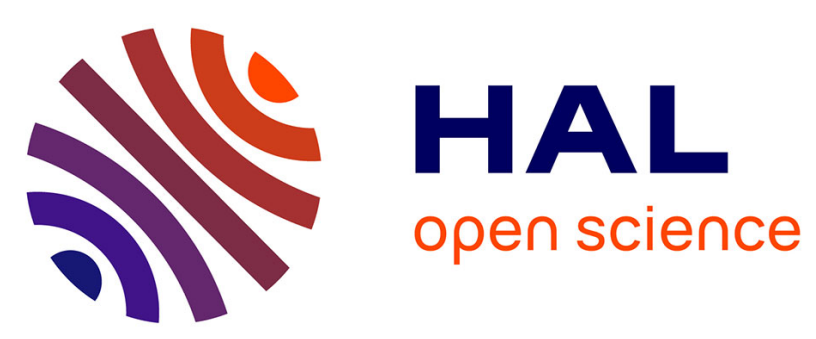

\title{
The Influence of Incidental Similarity on Self-Revelation in Response to an Intimate Survey
}

Angélique Martin, Nicolas Guéguen

\section{To cite this version:}

Angélique Martin, Nicolas Guéguen. The Influence of Incidental Similarity on Self-Revelation in Response to an Intimate Survey. Social behavior and personality, 2013, 41 (3), pp.353-356. 10.2224/sbp.2013.41.3.353 . hal-02000178

\section{HAL Id: hal-02000178 \\ https://hal.univ-rennes2.fr/hal-02000178}

Submitted on 29 May 2019

HAL is a multi-disciplinary open access archive for the deposit and dissemination of scientific research documents, whether they are published or not. The documents may come from teaching and research institutions in France or abroad, or from public or private research centers.
L'archive ouverte pluridisciplinaire HAL, est destinée au dépôt et à la diffusion de documents scientifiques de niveau recherche, publiés ou non, émanant des établissements d'enseignement et de recherche français ou étrangers, des laboratoires publics ou privés. 


\title{
THE INFLUENCE OF INCIDENTAL SIMILARITY ON SELF- REVELATION IN RESPONSE TO AN INTIMATE SURVEY
}

\author{
AngÉLIQUe Martin ANd Nicolas GuÉGUen \\ University of South Brittany
}

\begin{abstract}
Because it has been found that people are more willing to help someone with whom they believe they have something in common (Burger, Messian, Patel, del Prado, \& Anderson, 2004), we hypothesized that people would become less reluctant to respond to questions on intimate topics when these questions were asked by an interviewer who shared an incidental similarity with the respondent. A male or a female confederate approached, respectively, female and male passers-by seeking their participation in a survey about sexual behavior, in which the questions became increasingly intimate. At the beginning of the survey, the interviewer pointed out (similarity condition) or did not point out (no similarity condition) that he/she and the participant shared the same birth date. It was found that, compared with participants in the no similarity condition, participants in the similarity condition responded to more questions.
\end{abstract}

Keywords: incidental similarity, intimate topics, self-revelation, strangers, social relationships.

Some researchers in the social psychology literature have demonstrated that similarity between two strangers is associated with a more positive relationship during their first encounter. Burger, Messian, Patel, del Prado, and Anderson (2004) found that undergraduates who believed they shared birthday, first name, or fingerprint similarities with a confederate were more likely to comply with a request by the confederate to read an essay. Guéguen, Pichot, and Le Dreff (2005) found that students contacted by email soliciting their participation in a survey on food habits were more likely to agree to respond when the requester had the same surname. Oates and Wilson (2002) found the same effect when they conducted a study in which they used similar first names for the sender and the receiver.

Angélique Martin and Nicolas Guéguen, Department of Social Sciences, University of South Brittany. Correspondence concerning this article should be addressed to: Nicolas Guéguen, Université de Bretagne-Sud, UFR LSHS, 4 rue Jean Zay, BP92116, Lorient, France. Email: nicolas.gueguen@ univ-ubs.fr 
The results in these studies seem to show that incidental similarity fosters social relationships. These positive effects on social relationships of incidental similarity between two individuals are in accordance with the proposal by Heider (1958) that incidental similarities create a sense of association between people. This, in turn, leads to the enhancement of positive perception or compliance behavior. Guéguen, Martin, and Meineri (2011) found that as people who were approached on the street and asked to participate in a survey spent more time near a confederate with whom they shared incidental similarity, incidental similarity could create a higher degree of intimacy with the confederate.

There are a host of studies in which researchers report that they have found people are reluctant to respond to surveys on intimate topics (see Tourangeau \& Yan, 2007). Because incidental similarity has been associated with greater attraction to, and positive behavior toward, the similar individual, we hypothesized that individuals who were interviewed by someone who shared an incidental similarity with them would be less reluctant to respond to intimate questions in a survey on sexual behavior.

\section{Method}

In a field setting, passersby in the street were solicited to respond to an interview that included highly intimate questions regarding their sexual behavior. Fifty-seven women with a mean age of 22.8 years (29 in the similarity condition and 28 in the no similarity condition) and 57 men with a mean age of 23.1 years (30 in the similarity condition and 27 in the no similarity condition) agreed to respond to a survey conducted by two interviewers ( 1 female, 20 years; 1 male, 21 years), each of whom interviewed only participants of the opposite sex. The people who agreed to participate in the survey were first asked for their birth date and then presented with 11 questions that became progressively more intimate and which were possibly embarrassing. In the first part of the survey, there were four questions on demographic data (i.e., birth date, marital status). In the second part questions were on so-called "soft" and moderately intrusive topics associated with sexual behavior (i.e., age of first sexual intercourse), and the third part used taboo questions focusing on highly intimate sexual practices (i.e., Have you ever been in a sex shop? Do you use sex toys?). In one experimental condition, the interviewer was instructed to say that he/she had the same birth date as the respondent. The number of responses was used as the dependent variable in analyses. 


\section{Results and Discussion}

For each participant, a score was calculated by tabulating 1 point for each question answered. With male participants, a mean of $6.84(S D=1.56)$ was found in the similarity condition and $5.64(S D=1.51)$ in the no similarity condition. With female participants, a mean of $6.46(S D=1.49)$ was found in the similarity condition and $5.58(S D=1.62)$ in the no similarity condition. A 2 (confederate gender) $\times 2$ (experimental condition) analysis of variance (ANOVA) revealed a main effect of experimental condition, $F(1,108)=12.65, p<.001, \eta p^{2}=.14$. Neither the main effect of confederate gender, $F(1,108)=0.57, p=.45, \eta p^{2}=$ .01 , nor the interaction effect of confederate gender and experimental condition, $F(1,108)=0.30, p=.58, \eta p^{2}<.002$, was statistically significant.

These results show that participants were less reluctant to respond to intimate questions associated with their sexual behavior when they thought that they had the same birth date as the interviewer. Our results may be explained by the feelings of similarity activated between the interviewer and the participants in our experiment. Results in some studies in which social influence techniques have been examined have indicated that feelings of similarity are associated with a high level of willingness for self-revelation. For example, in a counseling context, Pattison (1973) found that when the counselor touched clients (i.e., had tactile contact) those clients evaluated the counselor to be more similar and closer to them, and proceeded to engage in more self-exploration than did clients who were not touched. Recently, researchers have also found that verbal or nonverbal mimicry creates feelings of similarity in participants. For example, Guéguen (2009) found that a woman who mimicked a man was perceived by that man to be close and similar to him. In our experiment we did not use mimicry or tactile contact to create feelings of similarity. Instead we used incidental similarity related to participants' birth dates. We found that participants in our similarity condition revealed more intimate information than did participants in our no similarity condition. It seems possible that knowing that the interviewer was born on the same day created a feeling of closeness with the interviewer for the participants and this made them less reluctant to provide personal, intimate information. Further studies should be conducted in which researchers simulate a condition of incidental similarity such as we used in this study to examine the mediated effect of a feeling of closeness when similarity is created.

\section{References}

Burger, J. M., Messian, N., Patel, S., del Prado, A., \& Anderson, C. (2004). What a coincidence! The effects of incidental similarity on compliance. Personality and Social Psychology Bulletin, 30, 35-43. http://doi.org/ddktc9 
Guéguen, N. (2009). Mimicry and seduction: An evaluation in a courtship context. Social Influence, 4, 249-255. http://doi.org/fvww47

Guéguen, N., Martin, A., \& Meineri, S. (2011). Similarity and social interaction: When similarity fosters implicit behavior toward a stranger. The Journal of Social Psychology, 151, 671-673. http://doi.org/bssjwf

Guéguen, N., Pichot, N., \& Le Dreff, G. (2005). Similarity and helping behavior on the web: The impact of the convergence of surnames between a solicitor and a subject in a request made by e-mail. Journal of Applied Social Psychology, 35, 423-429. http://doi.org/d4wjc6

Heider, F. (1958). The psychology of interpersonal relations. New York: Wiley.

Oates, K., \& Wilson, M. (2002). Nominal kinship cues facilitate altruism. Proceedings of the Royal Society of London. Series B: Biological Sciences, 269, 105-109. http://doi.org/b4htrv

Pattison, J. (1973). Effects of touch on self-exploration and the therapeutic relationship. Journal of Consulting and Clinical Psychology, 40, 170-175. http://doi.org/bw2xkn

Tourangeau, R., \& Yan, T. (2007). Sensitive questions in surveys. Psychological Bulletin, 133, 859-883. http://doi.org/fqchjm 